\title{
BAFF signaling drives interstitial transformation of mouse renal tubular epithelial cells in a Pin1-dependent manner
}

\author{
Haiyan Xu ${ }^{1}$ (D) $\cdot$ Dan Song ${ }^{1} \cdot$ Renfang Xu ${ }^{1} \cdot$ Xiaozhou He $^{1}$
}

Received: 25 January 2021 / Accepted: 26 May 2021 / Published online: 14 June 2021 / Handling Editor: Tetsuji Okamoto

(C) The Author(s) 2021

\begin{abstract}
Aberrant expression of B cell-activating factor belonging to TNF superfamily (BAFF) and its receptors results in abnormal biological activities in hematopoietic and non-hematopoietic cells and is closely associated with the occurrence and development of various diseases. However, the biological significance and potential mechanisms underlying BAFF signaling in renal tubular epithelial cells (RTECs) remain unknown. This study aimed to investigate the biological role of BAFF signaling in RTECs. Mice primary RTECs were applied. The proliferation status and apoptotic rates were examined by MTS assay and flow cytometry, respectively. The expression of BAFF and its receptors was analyzed via flow cytometry and sodium ion transport function, and cytokeratin-18 expression was detected through immunofluorescence staining. In addition, Pin1 was knocked down via siRNA and its expression was assessed through reverse transcription PCR. Lastly, western blotting was performed to analyze E-cadherin, a-SMA, and Pin1 expression. Results suggested that BAFF-R was significantly upregulated upon IFN- $\gamma$ stimulation, and enhancement of BAFF signaling promoted cell survival and reduced their apoptotic rate, while simultaneously reducing the epithelial phenotype and promoting the interstitial transformation of cells. Furthermore, Pin1 was significantly increased, along with the upregulation of BAFF signaling in the RTECs, and participated in interstitial transformation induced by BAFF signaling. Collectively, the present results elucidate the potential mechanism of loss of normal function of RTECs under long-term high dose of BAFF stimulation provides a potential therapeutic target for renal interstitial fibrosis, and underlining mechanisms of shortening of long-term outcomes of kidney allografts via augmenting of BAFF signaling.
\end{abstract}

Keywords BAFF $\cdot$ Renal tubular epithelial cells $\cdot$ Interstitial transformation $\cdot$ Pin 1

\section{Background}

B cell-activating factor belonging to TNF superfamily (BAFF) is a type II transmembrane protein belonging to the tumor necrosis factor superfamily and is highly conserved across different species. Physiological expression levels of BAFF are generally low in myeloid cells. In the presence of

Xiaozhou $\mathrm{He}$

hyx@suda.edu.cn

Haiyan Xu

xuhaiyan09@163.com

Dan Song

song_dan20@163.com

Renfang Xu

xurenfang20@163.com

1 Urology Department, Third Affiliated Hospital of Soochow University, 185\# Juqian Street, Changzhou 213003, China cytokines, such as IFN- $\gamma$ or TNF- $\alpha$, BAFF is significantly upregulated (Schneider et al. 1999). BAFF has three candidate receptors, BAFF receptor (BAFF-R), transmembrane activator and CAML interactor (TACI), and $\mathrm{B}$ cell-maturation antigen (BCMA). Among these, BAFF-R can only specifically bind to BAFF. These receptors are usually expressed on B cells at different stages of development. Different biological phenomena occur when BAFF binds to each of these receptors. The BAFF/BAFF-R signaling pathway transduces an important survival signal to late-transitional B lymphocytes and sustains their self-stabilization (Mackay and Schneider, 2009).

However, BAFF and its receptors are also expressed and play physiological roles in non-hematopoietic cells. For instance, salivary epithelial cells express BAFF when stimulated with dsRNA viruses (Ittah et al. 2008; Ittah et al. 2009), and the signal is transduced through the BAFF/BAFF-R pathway promotes the survival of these cells in an autocrine manner (Lahiri et al. 2014). Human respiratory epithelial cells express 
BAFF upon activation of Toll-like receptor signaling (McNamara et al. 2013; Alturaiki et al. 2018), and aberrant BAFF expression is potentially involved in local IgE production (Xu et al. 2008). BAFF is upregulated in lesional keratinocytes in individuals with cutaneous lupus erythematosus, and upregulation of BAFF/BAFF-R signaling potentially influences the biological activity of endothelial progenitor cells in systemic lupus erythematosus (SLE) (Jackson and Davidson, 2019). Furthermore, renal tubular epithelial cells (RTECs) express BAFF, which is associated with the histopathological activity of diffuse proliferative lupus nephritis, and in vitro assays have revealed an autocrine loop of BAFF with its cognate receptors on RTECs (Schwarting et al. 2018).

During kidney transplantation, BAFF upregulation is closely associated with the rejection of renal transplants (Friebus-Kardash et al. 2018). Generally, upregulation of BAFF signaling leads to overactivation and/or prolonged survival of B cells, or T cells, resulting in immunopathological injury (Mackay and Schneider, 2009). We previously reported that BAFF and its receptors are aberrantly upregulated on RTEC in renal allografts, which is closely correlated with the progression of chronic rejection (Xu et al. 2012).

Chronic antibody-mediated rejection, a particular type of inflammatory response, is the major cause of graft loss (Lefaucheur and Loupy, 2018). Along with rejected allografts, renal interstitial fibrosis and tubular atrophy (IF/TA) are the two characteristic manifestations. RTECs may not only be victims but also active participants in graft rejection (Nguan and $\mathrm{Du}, 2009)$. As a forgoing barrier, RTECs are subjected to various exogenous and endogenous stimuli, which they are susceptible to (Lu et al. 2019; Wang et al. 2019). This raises the question of whether BAFF signaling plays an important role in the morphology and function of RTECs during renal allograft antibody-mediated rejection. Local renal interstitial inflammation can induce interstitial transformation of RTECs during interstitial fibrosis. However, no studies have investigated whether aberrant upregulation of BAFF signaling in RTECs involves in the epithelial-mesenchymal transition (EMT) of RTECs. Such information would not only facilitate further studies on the mechanism underlying the mesenchymal transition of RTECs, the biological function of BAFF signaling but also elucidate the progression of renal tubular atrophy and renal interstitial fibrosis in renal transplant allografts. Pin1 is one of the molecules regulated by BAFF signaling in malignant B cells (Secreto et al. 2014), and it may play key role during EMT induction (Nakada et al. 2019). While no direct evidence is available regarding the role of Pin1 on the characteristics of RTECs upon upregulation of BAFF signaling.

In this study, mouse primary renal tubular epithelial cells were cultured, and in vitro analyses were performed to investigate the potential role of BAFF signaling in RTECs, and the function of Pin1 was also explored.

\section{Materials and methods}

Animals Six-to-eight-week-old male C57BL/6 mice were purchased from CAVENS (SCXK(SU)2-11-003) and housed in a specific pathogen-free facility under a 12:12-h light-dark cycle with ad libitum access to food and water. Animal experiments were approved by the Academic Committee of Soochow University.

Culturing of primary RTECs RTECs were extracted from mice using previously reported methods (Valente et al. 2011). In brief, mice were euthanized, and the kidneys were immediately excised and placed in ice-cold complete media in HBSS (Hyclone, Marlborough, MA) supplemented with $1 \%$ penicillin-streptomycin (Hyclone). Thereafter, the renal capsule was dissected out, and sagittal sections of the renal cortex were obtained and the medulla was discarded. Further, cortical tissue was minced in complete medium with collagenase I (1 $\mathrm{mg} / \mathrm{mL}$, Sigma-Aldrich, St. Louis, MO) and soybean trypsin inhibitor $\left(100 \mu \mathrm{g} / \mathrm{mL}\right.$, Sigma-Aldrich) and incubated at $37^{\circ} \mathrm{C}$ for $45 \mathrm{~min}$ with frequent mixing. The same volume of ice-cold HBSS was added into tubules to terminate the digestion step. The digestion product was sieved successively with $150-\mu \mathrm{m}$ and $75-\mu \mathrm{m}$ mesh sieves, and the filtrate was collected and seeded on collagen-treated plates in a selection culture medium comprising DMEM:F12 culture media (Gibco, Waltham, MA) supplemented with $10 \mathrm{~mL} / \mathrm{L}$ penicillin-streptomycin (Hyclone), $50 \mathrm{nmol} / \mathrm{L}$ hydrocortisone (Sigma-Aldrich), epidermal growth factor, insulin/transferring/selenium $(10 \mu \mathrm{g} /$ $\mathrm{mL} / 5.5 \mu \mathrm{g} / \mathrm{mL}$, Gibco), and tri-iodothyronine (Gibco), in an incubator $\left(37^{\circ} \mathrm{C}, 5 \% \mathrm{CO}_{2}\right)$ and cultured to $80 \%$ confluence for subculturing. Cells of the second and third passages were used for subsequent experiments.

Cell proliferation and apoptosis assays In total, $8 \times 10^{4}$ cells/ well of primary RTECs were seeded in a 96-well plate. The stimulated groups were cultured with $\mathrm{rBAFF}(2 \mathrm{ng} / \mathrm{mL}, 5 \mathrm{ng} /$ $\mathrm{mL}$, and $20 \mathrm{ng} / \mathrm{mL}$, respectively, R\&D, Minneapolis, $\mathrm{MN}$ ), or $20 \mathrm{ng} / \mathrm{mL}$ rBAFF (R\&D) after stimulation with $200 \mathrm{ng} / \mathrm{mL}$ BAFF-R-Fc fusion protein (R\&D) for $30 \mathrm{~min}$. Cells without cytokines treatment or $200 \mathrm{ng} / \mathrm{mL}$ BAFF-R-Fc fusion protein treatment alone were set as controlled groups.

For the cell proliferation assay, after $48 \mathrm{~h}$ of incubation, MTS reagents (3-(4,5-dimethylthiazol-2-yl)-5-(3carboxymethoxyphenyl)-2-(4-sulfophenyl)-2H-tetrazolium, Promega, Madison, WI) were added in each well. After $4 \mathrm{~h}$, $\mathrm{OD}_{490}$ values were detected using a SPECTRA Max 384 reader (Spectra Max 384, Molecular Devices, San Jose, CA).

For the cell apoptosis assay, the stimulated cells were cultured with $20 \mathrm{ng} / \mathrm{mL} \mathrm{rBAFF}$, and the inhibited groups were cultured with $500 \mathrm{ng} / \mathrm{mL}$ BAFF-R-Fc fusion proteins (R\&D) for $30 \mathrm{~min}$ and then treated with $20 \mathrm{ng} / \mathrm{mL}$ rBAFF (R\&D). After $48 \mathrm{~h}$, cells were harvested and treated using the protocol 
of Multiscience (Hangzhou, China). In brief, $2 \times 10^{5}$ cells/tube of treated primary RTECs was diluted with $500 \mu \mathrm{L} 1 \times$ binding buffer, and $5 \mu \mathrm{L}$ Annexin V-FITC and $10 \mu \mathrm{L}$ PI were added, gently mixed, and incubated at ambient temperature for $5 \mathrm{~min}$. Thereafter, cells were analyzed through flow cytometry (FCM). Experiments were performed in triplicate.

\section{Analysis of BAFF and its receptor expression in RTECs by FCM} In total, $8 \times 10^{4}$ cells/well of primary RTECs were seeded in a 24-well plate and cultured at $37^{\circ} \mathrm{C}$ in $5 \% \mathrm{CO}_{2}$ in a conditioned medium. Thereafter, $500 \mathrm{U} / \mathrm{mL}$ IFN- $\gamma$ (R\&D) was supplemented in the medium when approached $80 \%$ confluence. After $48 \mathrm{~h}$, cells were digested with $0.25 \%$ trypsin and centrifuged for $5 \mathrm{~min}$ at $1000 \mathrm{r} / \mathrm{min}$ (the centrifugation radius was $8 \mathrm{~cm})$. The cell pellets were resuspended in PBS containing $5 \%$ FBS, and BAFF and BAFF-R expression levels were assessed through FCM.

Approximately $2 \times 10^{5}$ cells were incubated with FITClabeled rat-anti-mBAFF antibody (Abcam, Cambridge, MA) or PE-labeled anti-mBAFF-R (BD, Franklin Lakes, NJ), antimBCMA (R\&D), and anti-mTACI (Abcam) antibody in each well for $30 \mathrm{~min}$ at $4^{\circ} \mathrm{C}$. Control cells were cultured in medium not containing IFN- $\gamma$. Experiments were performed in triplicate.

Cytokeratin (CK)-18 detection To determine the expression level of cytokeratin-18 (CK-18) in RTECs, the cells were serum-starved overnight in DMEM:F12, or treated with 500 $\mathrm{ng} / \mathrm{mL}$ BAFF-R-Fc fusion protein (R\&D) for $30 \mathrm{~min}$ and 5 $\mathrm{ng} / \mathrm{mL}$ recombinant BAFF ( $\mathrm{BAAFF}, \mathrm{R} \& \mathrm{D}$ ) or stimulated with $5 \mathrm{ng} / \mathrm{mL} \mathrm{rBAFF}$ alone. Cells without cytokines treatment or $500 \mathrm{ng} / \mathrm{mL}$ BAFF-R-Fc fusion protein treatment alone were set as controlled groups. When cells were cultured to $90 \%$ confluence (approximately $48 \mathrm{~h}$ ), they were stained with rabbit anti-mCK-18 polyclonal antibody (Sigma-Aldrich). In brief, the following method was used: treatment with $4 \%$ paraformaldehyde for $15 \mathrm{~min}$; treatment with $0.3 \%$ Triton-X-100 at ambient temperature for $10 \mathrm{~min}$; blocking with BSA-TBS at ambient temperature for Sigma-Aldrich at $4^{\circ} \mathrm{C}$ overnight; four PBS washes, 5 min each; incubation with goat anti-mouse FITC-Ig antibody (1:100, Sigma-Aldrich) for $45 \mathrm{~min}$ in the dark; addition of the anti-quencher reagent (Invitrogen, Franklin Lakes, CA); and observing using a fluorescence microscope (Leica, Wetzlar, Germany). Between each procedure, at least three PBS washes were carried out. Fluorescence intensity was analyzed in the images, using ImageJ software (National Institutes of Health, Bethesda, $\mathrm{MD})$. Experiments were performed in triplicate.

Fluorescein sodium transport test The reagent dose and experimental groups were the same as that for CK-18 detection experiments. Primary RTECs were cultured to $90 \%$ confluence, washed with HBSS (warm-up in a water bath at $37^{\circ} \mathrm{C}$ ) once, and incubated in $\mathrm{HBSS}$ at $37^{\circ} \mathrm{C}$ for $10 \mathrm{~min}$. Thereafter, the cells were incubated with $1 \mathrm{~mL}$ HBSS with $1 \times 10^{-5} \mathrm{~mol} / \mathrm{L}$ fluorescein sodium at $37^{\circ} \mathrm{C}$ for $20 \mathrm{~min}$. Ice-cold PBS was then added into the wells to terminate the reaction, followed by four rapid washes with ice-cold PBS. Fluorescein staining intensity was determined from fluorescence microscopic (Leica) images through ImageJ. Experiments were performed in triplicate.

Pin1 siRNA co-transfection Briefly, primary RTECs were cultured in DMEM:F12 medium without penicillin-streptomycin, and allowed to approach $60-80 \%$ confluence. Thereafter, the cells were incubated with Pin1 siRNA in accordance with the manufacturer's instructions (RiboBio, Guangzhou, China). The final concentration of Pin1 siRNA mixture was $40 \mathrm{nM}$, of which $400 \mu \mathrm{L}$ of the final mixture was gently added into each well, and the cells were incubated for $6 \mathrm{~h}$ at $37^{\circ} \mathrm{C}$ in a $\mathrm{CO}_{2}$ incubator. Thereafter, $500 \mu \mathrm{L}$ of $2 \times$ completed medium without antibiotics were added in each well, mixed gently, and further incubated for $24 \mathrm{~h}$. Experiments were performed in triplicate.

Reverse transcription PCR (RT-PCR) analysis The effects of siRNA were analyzed through RT-PCR. Total RNA was extracted using the RNAiso Plus kit (TaKaRa, Dalian, China) in accordance with the manufacturer's instructions. cDNA was prepared using PrimeScript 1st Strand cDNA synthesis Kit (TaKaRa). mRNA levels were determined through PCR using Premix Taq (TaKaRa Taq Version 2.0 plus dye, TaKaRa). Electrophoresis was performed to observe the size of the PCR products.

Western blots In total, $4 \times 10^{5}$ cells/well of primary RTECs were seeded in a 96-well plate. In the rBAFF stimulation group, the final $\mathrm{rBAFF}$ concentration was $200 \mathrm{ng} / \mathrm{mL}$. In the BAFF-R-Fc and rBAFF sequential stimulation group, cells were first stimulated with $1000 \mathrm{ng} / \mathrm{mL}$ BAFF-R-Fc fusion protein for $30 \mathrm{~min}$ at $37^{\circ} \mathrm{C}$, and then $200 \mathrm{ng} / \mathrm{mL}$ of $\mathrm{rBAFF}$ was added in the medium. In the Pin1 siRNA-transfected cells, the final concentration of Pin 1 siRNA was $40 \mathrm{nM}$. In the Pin1 siRNA-transfected and rBAFF-stimulated cells, after primary RTECs were transfected with $40 \mathrm{nM}$ Pin1 siRNA for $24 \mathrm{~h}$, the medium was discarded and replaced by a completed medium containing $200 \mathrm{ng} / \mathrm{mL}$ rBAFF. In Pin 1 siRNAtransfected, BAFF-R-Fc-treated, and rBAFF-stimulated cells, the same aforementioned procedure was followed, with Pin 1 siRNA being substituted with control siRNA or no siRNA among the control cells.

After $48 \mathrm{~h}$ of culture under final conditions, the total cell lysates were isolated using RIPA buffer (Sigma-Aldrich) with a protease and phosphatase inhibitor cocktail (Thermo Scientific, Franklin Lakes, CA), and quantified using the Enhanced BCA Protein Assay kit (Beyotime, Nantong, China). 
Proteins were through SDS-PAGE and electro-transferred onto a nitrocellulose membrane (Bio-Rad, Hercules, CA). After $1 \mathrm{~h}$ of incubation with $5 \%$ BSA, the membranes were probed overnight with the following primary antibodies: antiPin1 (1:400, Santa Cruz, TX), anti-E-cadherin (1:1000, CST, Danvers, MA), anti- $\alpha$-SMA (1:1000, CST), and anti- $\beta$-actin (1:1000, CST) antibodies. After washing, the membranes were probed with an HRP-conjugated secondary antibody (1:1000, CST) in blocking solution for $1 \mathrm{~h}$ at ambient temperature. HRP activity was assessed using the chemiluminescence kit (Pierce, Appleton, WI) in accordance with the manufacturer's instructions. The images were analyzed using Image Lab Software (Bio-Rad).

Statistical analysis Data are presented as mean $(\overline{\mathrm{x}}) \pm \mathrm{SD}$ values and analyzed using SPSS 19.0 software (SPSS Inc., Chicago, IL). Between-group comparisons were performed using a paired samples $t$ test, with $P<0.05$ considered statistically significant.

\section{Results}

Identification of primary mouse RTECs The primary cells we obtained had a typical polygonal cobblestone-like morphology, with tight junctions among them, with good refraction and relatively large sizes (Fig. $1 A$ ).

CK-18 was particularly expressed on epithelial cells, potentially serving as a biomarker of primary RTECs. Immunofluorescence staining revealed that the rate of $\mathrm{CK}$ 18 positivity in the primary cells was $>90 \%$ (Fig. 1B). Ion transport function is another important function of epithelial cells. We investigated the $\mathrm{Na}^{+}$transferability through immunofluorescence. We observed a gradual increase in the intracellular fluorescence intensity with time (Fig. 1C).

To observe the growth status of primary RTECs, we counted the cell number every $2 \mathrm{~d}$. The results suggested that cells could grow well for about $14 \mathrm{~d}$ (3 generations) (Fig. 1D). And BAFF-R expression was stably on primary RTECs through the initial 3 generations, and then it went down (Fig. 1E). Moreover, the expression rate of CK-18 was basically consistent with BAFF-R (Fig. $1 F$ ).

\section{BAFF-R was significantly upregulated on primary RTECs after} IFN- $\gamma$ stimulation FCM assays revealed a significant increase in the mean fluorescence intensity (MFI) of BAFF-R on RTECs after IFN- $\gamma$ stimulation (4166.25 \pm 913.91 vs 3602.75 \pm 162.47 .58 , respectively; $P<0.05$ ); however, the expression of BAFF, BCMA, and TACI did not vary significantly $(1027.40 \pm 98.5$ vs $1066.40 \pm 143.42,2392.32 \pm 178.21$ vs $2543.23 \pm 209.18,1629.84 \pm 197.35$ vs $1737.64 \pm 338.05$, respectively; $P>0.05$ ) (Fig. 2).
BAFF upregulation promoted proliferation and inhibited apoptosis in primary RTECs The MTS assay revealed that, compared with blank control group (cont) and BAFF-R-Fc alone treatment group, $5 \mathrm{ng} / \mathrm{mL}$ and $20 \mathrm{ng} / \mathrm{mL} \mathrm{rBAFF}$ significantly promote proliferation in primary RTECs $(P<0.05)$, but the effect was not dose-dependent. Pre-treatment with BAFF-RFc fusion protein significantly mitigated the effect of $\mathrm{rBAFF}$ on RTECs, compared to treatment with $5 \mathrm{ng} / \mathrm{mL} \mathrm{rBAFF}$ $(1.477 \pm 0.050$ vs $1.532 \pm 0.058$, respectively; $P<0.05)$ (Fig. $3 A)$

However, rBAFF stimulation significantly inhibited apoptosis in RTECs compared to control groups and BAFF-R-Fc alone treated groups $(39.850 \% \pm 8.544 \%$ vs $44.467 \% \pm 7.642 \%$; $39.850 \% \pm 8.544 \%$ vs $44.86 \pm 7.02$, respectively, $P<0.05)$. Furthermore, pre-treatment with BAFF-R-Fc fusion protein significantly mitigated the pro-apoptosis effect of rBAFF on RTECs $(42.950 \% \pm 8.330 \%$ vs $39.85 \% \pm 8.544 \% ; P<0.05)$ (Fig. 3B).

Upregulation of BAFF signaling reduced the epithelial characteristics of primary RTECs While BAFF upregulation reduced CK-18 expression, compared to the control cells and BAFF-R-Fc fusion protein-treated cells $(0.032 \pm 0.005$ vs $0.041 \pm 0.008 ; 0.032 \pm 0.005$ vs $0.04 \pm 0.003$. respectively; $P<0.05)$, pre-treatment with BAFF-R-Fc fusion protein significantly mitigated the effect of BAFF on CK-18 expression, compared to rBAFF treatment $(0.043 \pm 0.007$ vs 0.032 \pm 0.005 , respectively; $P<0.05$ ) (Fig. $4 A$ ).

Furthermore, BAFF upregulation significantly decreased $\mathrm{Na}^{+}$transferability in RTECs, compared to the control group and BAFF-R-Fc fusion protein treatment group $(0.011 \pm 0.003$ vs $0.016 \pm 0.006 ; 0.011 \pm 0.003$ vs $0.016 \pm 0.004$, respectively; $P<0.05)$. Moreover, pre-treatment with BAFF-R-Fc fusion protein significantly rescued $\mathrm{Na}^{+}$transfer activity in RTECs, which had initially decreased because of rBAFF stimulation $(0.020 \pm 0.007$ vs $0.011 \pm 0.003$, respectively; $P<0.05)$ (Fig. 4B).

Upregulation of BAFF signaling induced a mesenchymal transition in a Pin-1-dependent manner E-cadherin and a-SMA expression were assessed to analyze the effect of the upregulation of BAFF/BAFF-R signaling on RTECs. In this study, stimulation with a high concentration of rBAFF significantly downregulated E-cadherin $(0.403 \pm 0.04$ vs $0.744 \pm 0.05$, $P<0.05)$, but upregulated $\alpha$-SMA in the primary RTECs $(0.684 \pm 0.043$ vs $0.393 \pm 0.051, P<0.05)$. Furthermore, the effect of rBAFF could be mitigated by BAFF-R-Fc fusion protein $(0.684 \pm 0.035$ vs $0.733 \pm 0.05$ and $0.421 \pm 0.043$ vs 0.393 \pm 0.051 , respectively; $P<0.05$ ) (Fig. 5).

Pin 1 retained the WW domains (residues 1-39) at the Nterminal and the PPIase domain (residues 45-163) at the Cterminals (Verdecia et al. 2000; Chen et al. 2018). Pin1 reportedly affects substrate stability, and regulates TGF- $\beta 1$ expression, thus enhancing TGF- $\beta 1$-mediated fibrogenesis 

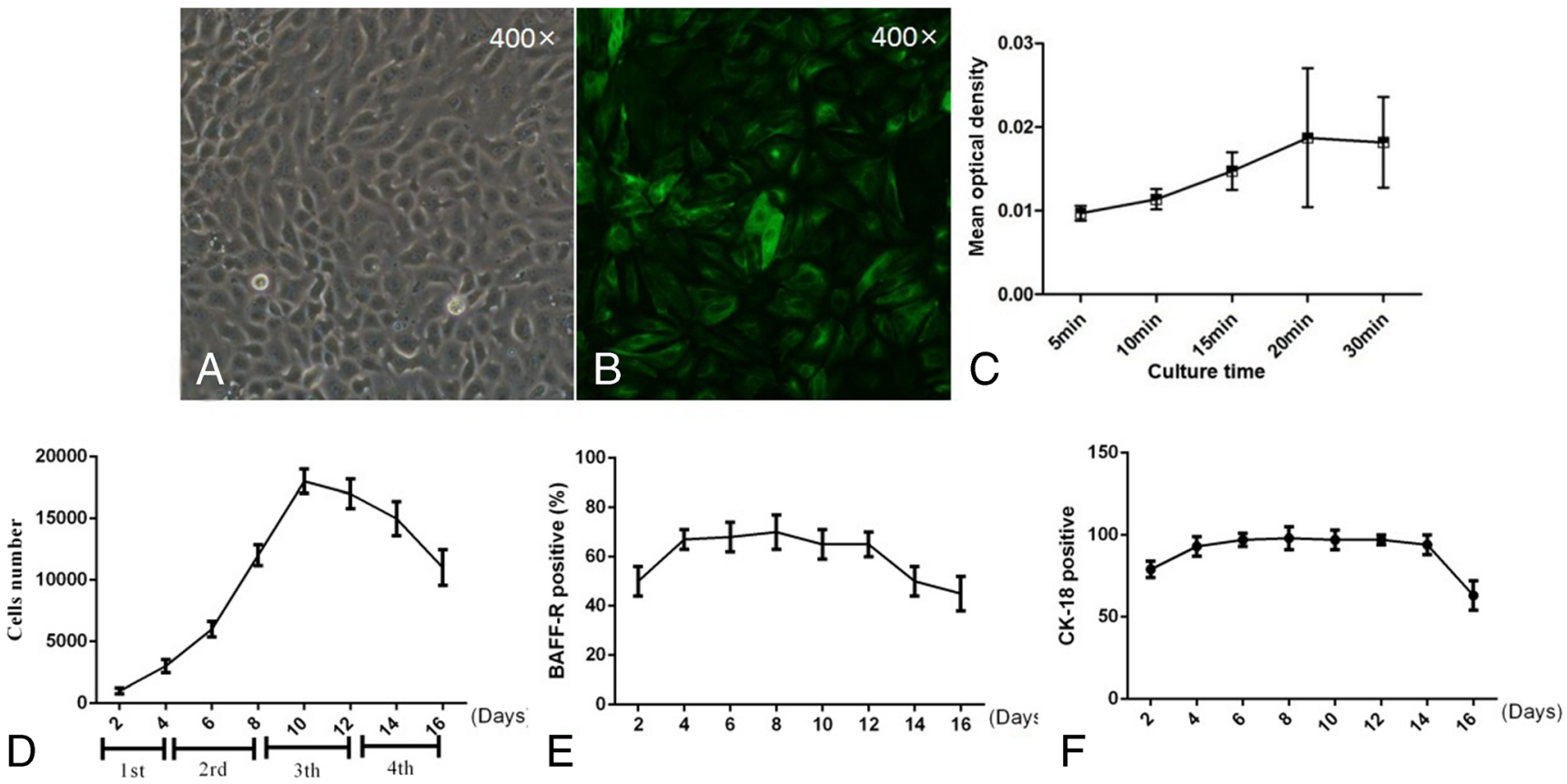

Figure 1. Identification of mice primary renal tubular epithelial cells (RTECs). (A) The cells displayed a typical polygonal cobblestone-like morphology, with good refraction and a relatively large cell size $(400 \times)$. $(B)$ Immunofluorescence staining revealed that the rate of CK-18 positivity in the primary cells was $>90 \%$. (C) The ability of $\mathrm{Na}^{+}$transfer was also tested through an immunofluorescence assay. Intracellular fluorescence intensity gradually increased with time. $(D)$ The growth curve of primary

RTECs. The cells took about $4 \mathrm{~d}$ to overgrow the flask and continued to grow well for nearly $10 \mathrm{~d}$. (E) BAFF-R expression was detected by flow cytometry every $2 \mathrm{~d}$. BAFF-R was stably expressed on primary RTECs during the initial 14 incubation days, and then it went down. $(F)$ CK-18positive population (\%) through the initial 16 incubation days, stained by immunofluorescence assays. It was shown that CK-18 was stably expressed for about $14 \mathrm{~d}$, and then it went down.

signaling (Matsuura et al. 2010; Inoue et al. 2019). In cells expressing BAFF- $\mathrm{R}_{\mathrm{H} 159 \mathrm{Y}}, \mathrm{rBAFF}$ stimulation increased the growth and survival of cells through the regulation of relevant genes including Pin1 (Secreto et al. 2014).

Herein, BAFF upregulation in primary RTECs significantly increases Pin 1 expression $(0.822 \pm 0.066$ vs $0.486 \pm 0.062$, respectively; $P<0.01$ ), and this effect could be inhibited through pre-treatment with BAFF-R-Fc fusion protein $(0.508 \pm 0.056$ vs $0.486 \pm 0.062$, respectively; $P<0.05)$ (Fig. 6). Pin1 siRNA was used to knock down Pin1. The optimal working concentration of Pin1 siRNA was $40 \mathrm{nM}$ (data not shown). In subsequent experiments, Pin1 silencing significantly upregulated E-cadherin and significantly downregulated $\alpha$-SMA through BAFF stimulation $(P<0.05)$. Furthermore,

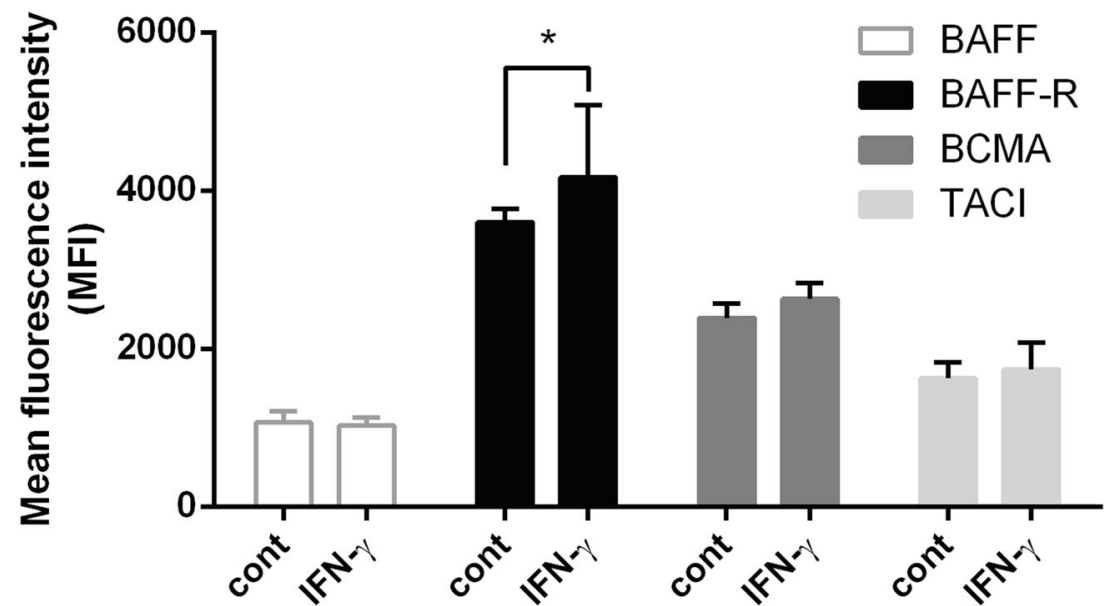

Figure 2. BAFF-R was significantly upregulated on primary renal tubular epithelial cells (RTECs) after IFN- $\gamma$ stimulation. Flow cytometry assays indicated that the mean fluorescence intensity of BAFF-R on
RTECs significantly increased after IFN $-\gamma$ stimulation $\left({ }^{*} P<0.05\right)$. However, the expression of BAFF, BCMA, and TACI expression did not vary significantly $(P>0.05)$. 


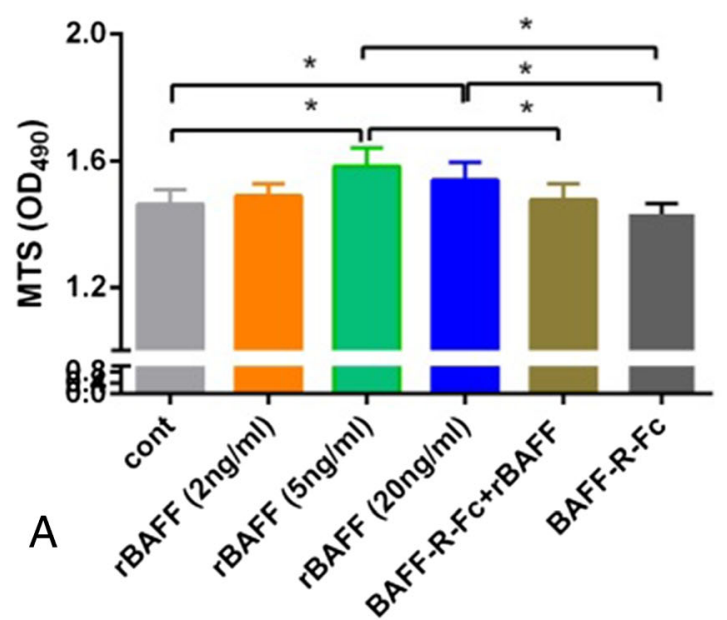

Figure 3. Upregulation of BAFF signaling promotes proliferation and decreases apoptosis in primary renal tubular epithelial cells (RTECs). (A) MTS assay indicated that $5 \mathrm{ng} / \mathrm{mL}$ and $20 \mathrm{ng} / \mathrm{mL}$ rBAFF significantly promoted proliferation in primary RTECs $\left({ }^{*} P<0.05\right.$, respectively), but the effect was not dose-dependent; pre-treatment with BAFF-R-Fc fusion

upon pre-treatment with BAFF-R-Fc fusion protein, no similar effects of Pin1 siRNA on RTECs were observed upon BAFF stimulation $(P<0.05$, Fig. 7).

\section{Discussion}

Renal tubules are a major component of the kidney and are vulnerable to various injuries including ischemia, proteinuria, toxins, and metabolic disorders. In response to injury, RTECs

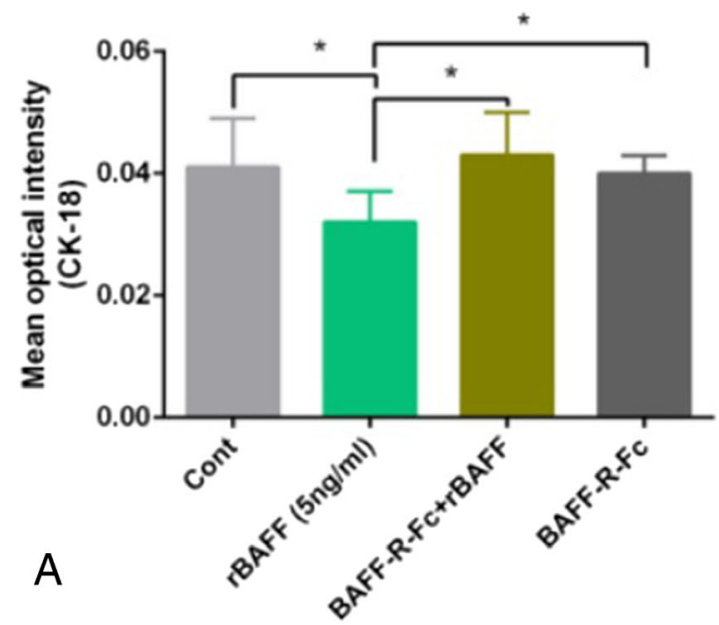

Figure 4. Upregulation of BAFF signaling decreased the epithelial characteristics of primary renal tubular epithelial cells (RTECs). (A) BAFF upregulation reduced CK-18 expression, compared to the control cells ( $\left.{ }^{*} P<0.05\right)$; however, pre-treatment with BAFF-R-Fc fusion protein significantly mitigated the effect of BAFF on CK-18 expression,

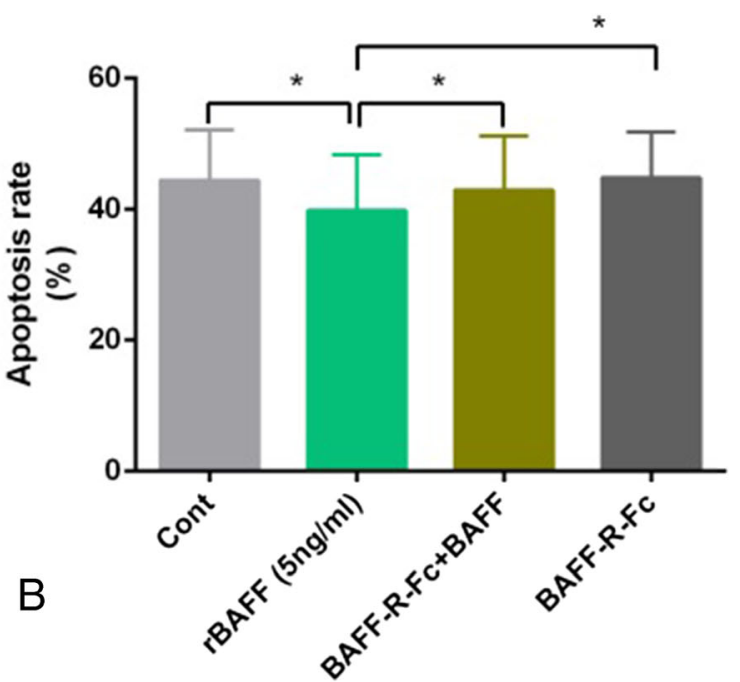

protein significantly mitigated the effect of rBAFF on RTECs, compared to $5 \mathrm{ng} / \mathrm{mL}$ rBAFF treatment $\left({ }^{*} P<0.05\right)$. (B) rBAFF stimulation significantly inhibited apoptosis in RTECs, compared to the control groups $\left({ }^{*} P<0.05\right)$. Furthermore, pre-treatment with BAFF-R-Fc fusion protein significantly reduced the effect of rBAFF on RTECs $\left({ }^{*} P<0.05\right)$.

can synthesize and secrete various bioactive molecules that drive interstitial inflammation and fibrosis. Furthermore, RTECs play an active role in progressive renal injury through mechanisms associated with the conversion into collagenproducing fibroblast phenotype, cell cycle arrest at both G1/ $\mathrm{S}$ and $\mathrm{G} 2 / \mathrm{M}$ checkpoints, and metabolic disorder (Allison. 2015; Liu et al. 2019). The suppression of interstitial transformation of RTECs can significantly reduce the accumulation of interstitial fibroblasts and mitigate tubule injury, thus delaying

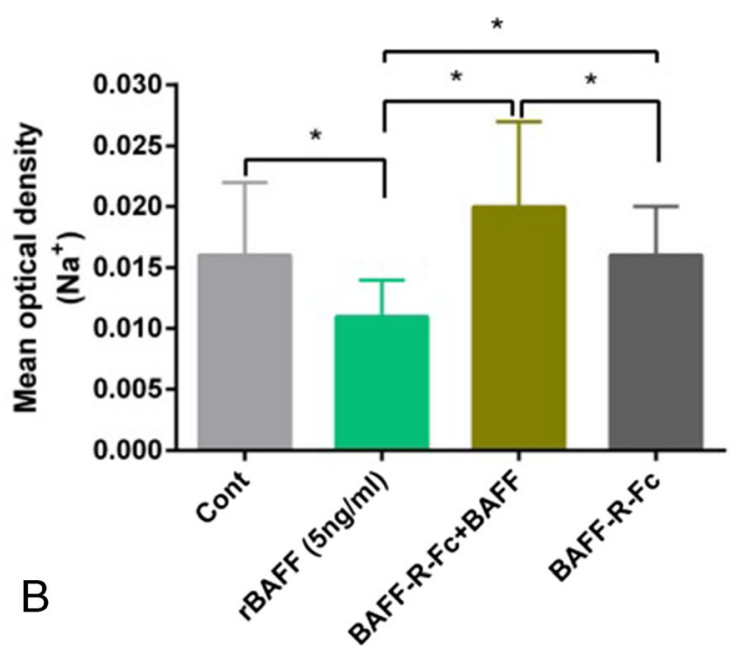

compared to rBAFF treatment $\left({ }^{*} P<0.05\right)$. (B) BAFF upregulation significantly decreased the transferability of $\mathrm{Na}^{+}$in RTECs $\left({ }^{*} P<0.05\right)$. Furthermore, pre-treatment with BAFF-R-Fc fusion protein significantly rescued $\mathrm{Na}^{+}$transferability in RTECs, which had initially decreased because of rBAFF stimulation $\left({ }^{*} P<0.05\right)$. 

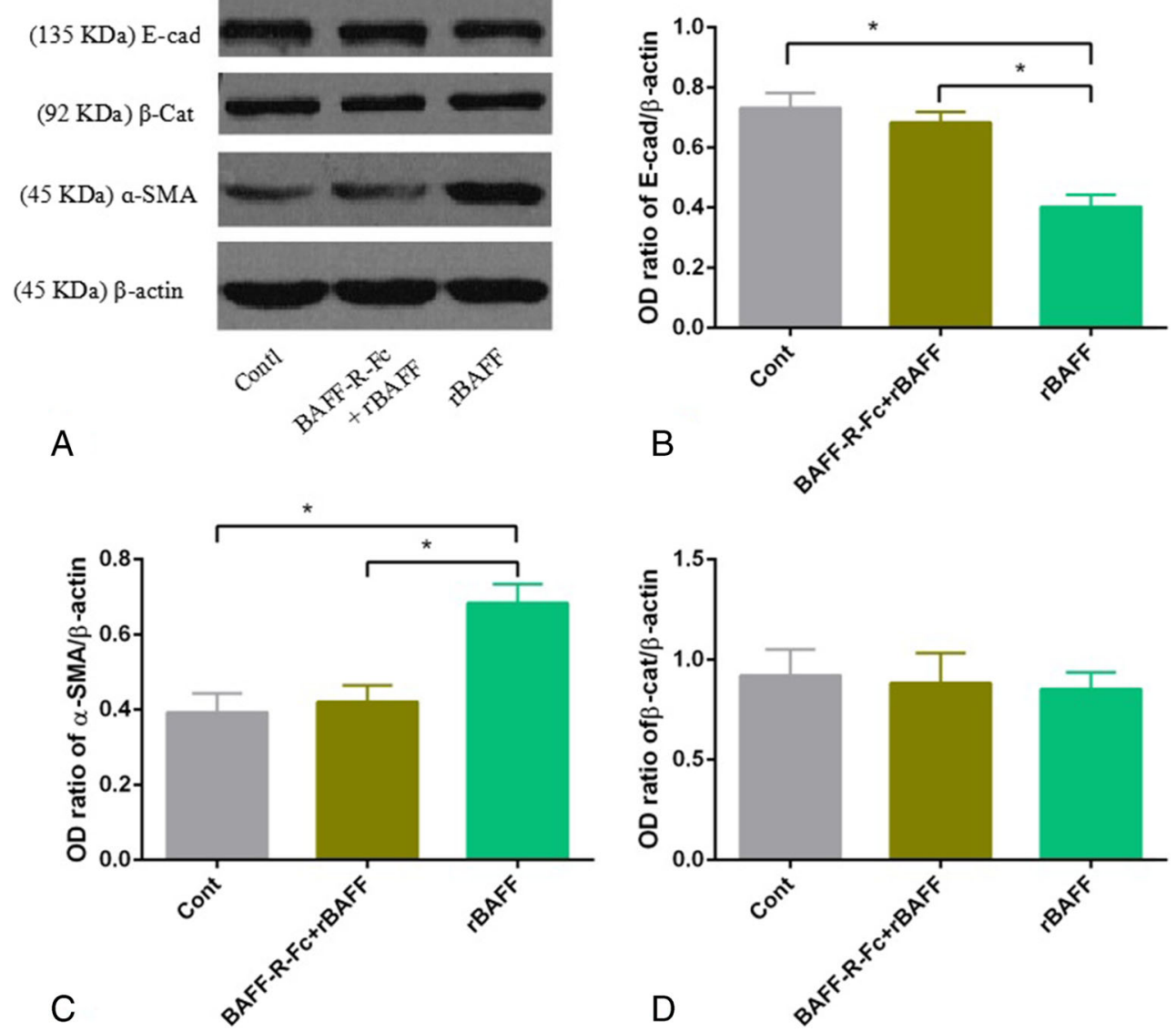

Figure 5. Upregulation of BAFF signaling stimulated interstitial transformation in primary renal tubular epithelial cells (RTECs). (A) The original western blot. The experimental groups were rBAFF stimulation, BAFF-R-Fc protein treatment and $\mathrm{rBAFF}$ stimulation group, and control group. E-cadherin (E-cad), $\beta$-catenin ( $\beta$-cat), and a-SMA were detected, and $\beta$-actin was considered the internal reference. $(B, C$,

$D$ ) The results of grayscale scanning indicated that rBAFF significantly downregulated E-cadherin but significantly upregulated a-SMA, and pretreatment of BAFF-R-Fc protein mitigated the effect of $\mathrm{rBAFF}$ on primary RTECs $\left({ }^{*} P<0.05\right)$. No significant effect of rBAFF and/or BAFF-R-Fc protein treatment was observed.

\section{( 18KDa) Pinl}

\section{(45 KDa) $\beta$-actin}
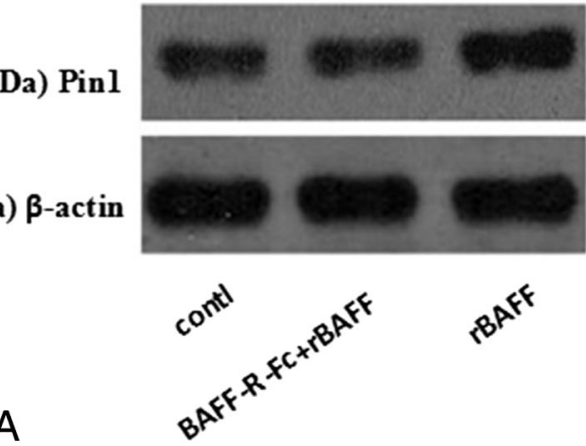

Figure 6. Pin1 was upregulated with the upregulation of BAFF signaling. (A) The original images of western blot. The experimental groups were the same as those indicated in Fig. 5. (B) The grayscale scanning results

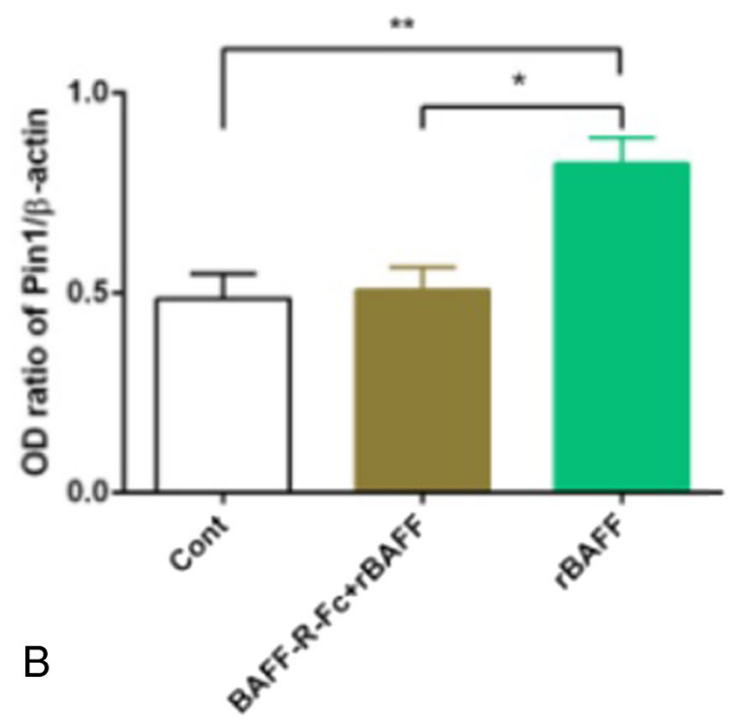

indicate that $\mathrm{rBAFF}$ stimulation significantly upregulated the expression of Pin $1\left({ }^{*} P<0.05 ;{ }^{* * *} P<0.01\right)$. 


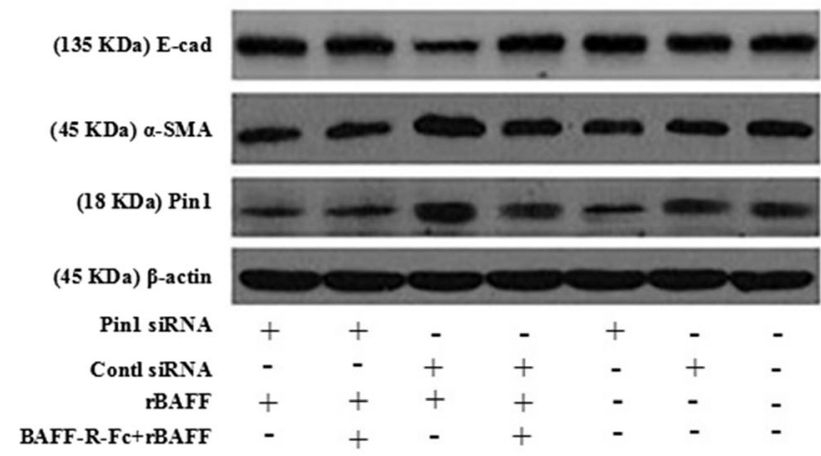

A

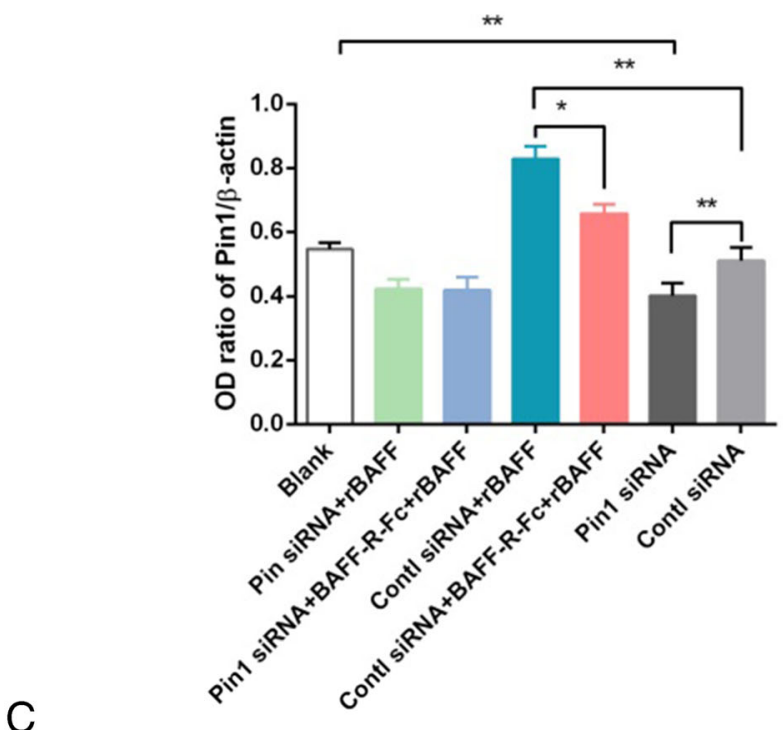

Figure 7. Pin1 is involved in interstitial transformation during BAFF signaling. (A) The original images of western blot. The effect of Pin1 siRNA and the control siRNA treatment were observed, in combination with $\mathrm{rBAFF}$ and BAFF-R-Fc protein treatment groups. $(B)$ The grayscale scanning results suggest that Pin1 siRNA knocked down Pin1 mRNA the occurrence of renal fibrosis and protecting renal function (Grande et al. 2015; Lovisa et al. 2015).

In renal allograft fibrosis, tubular atrophy is considered an interstitial fibrosis/tubular atrophy (IF/TA). IF/TA occurs in approximately $40 \%$ of kidney allografts at 3-6 mo after transplantation, its incidence increasing to $65 \%$ at $2 \mathrm{yr}$ after transplantation (Boor and Floege. 2015). To further enhance the long-term outcome of underlying recipients and allografts, it is necessary to illuminate the pathomechanism. Detailed studies on the mechanism underlying interstitial transformation of RTECs may yield a potential target for clinical treatment of renal interstitial fibrosis.

During interstitial transition in RTECs, epithelial markers including CK-18 and E-cadherin are downregulated or completely obliterated; however, mesenchymal markers including a-SMA are upregulated. This occurs along with a change in cell polarity and the formation of interconnecting intercellular structures and is finally accompanied by decreased cell function (Majo et al. 2019).

In this present study, BAFF-R was the only receptor with significantly upregulated expression when RTECs were stimulated by IFN- $\gamma$, and the expression of other two receptors, BCMA and TACI, did not vary significantly. When RTECs were challenged by enhancement of BAFF signaling, the ion transfer activity and the epithelial characteristics decreased, but mesenchymal characteristics increased. BAFF can bind to other two receptors, BCMA and TACI, in addition to its specific receptor, BAFF-R. To determine the function of BAFF signal, BAFF-R-Fc fusion protein was applied, which can bind to BAFF specifically and with high affinity. The 
results suggested that BAFF-R-Fc fusion protein could block or neutralize these effects.

For the rigor of the statement, we considered that BAFF signaling can drive interstitial transformation of mouse renal tubular epithelial cells. The present data obtained from the mouse primary RTECs and the characteristics of cells emulate those under in vivo conditions. Therefore, we considered that BAFF signal enhancement actively promotes interstitial transformation in RTECs. Persistent and aberrant upregulation of BAFF in recipients may be one of the primary causes of kidney allograft failure. Our results potentially provide an experimental basis for BAFF-targeted biotherapy because therapeutics targeting BAFF are now clinically available (Panzer. 2020).

To investigate the potential downstream signaling cascade of interstitial transition after BAFF stimulation, Pin1 was analyzed in RTECs. Pin1 is a unique enzyme, which isomerizes the cis-trans conformation between $\mathrm{pSer} / \mathrm{pThr}$ and proline residues, thus regulating the function, stability, and/or subcellular distribution of its target proteins, subsequently affecting the function of substrate proteins and participating in the regulation of various cell functions (Nakatsu et al. 2016; Nakatsu et al. 2020), and the catalytic activity of Pin 1 would potentially alter the phosphorylation status of various enzymes (Liu et al. 2016).

Pin1 is reportedly involved in the regulation of the epithelial-mesenchymal transition (Kim et al. 2009) and the expression of immune-related genes, inflammatory cytokines, and fibrogenic growth factors (Shen et al. 2005; Shen et al. 2012). Pin1 upregulation in mouse and human fibrotic liver tissues, and Pin1-dependent epithelial-mesenchymal transformation activation pathways are potentially associated with liver fibrosis (Yang et al. 2014). Moreover, Pin1 is reported to be a key regulator of extracellular matrix gene expression on administering a high-phosphate diet to mice (Shen et al. 2016). The present data indicate that the significant upregulation of Pin1 during interstitial transition of RTECs was induced by enhancement of the BAFF signal, and inhibition of Pin1 significantly weakened the interstitial transformation of RTECs by BAFF signals. These results indicate that Pin 1 plays an essential role during interstitial transformation in RTECs induced by BAFF signals.

A novel reciprocal loop of TGF- $\beta 1 /$ PML SUMOylation/ Pin1 leading to myocardial fibrosis may exist (Wu et al. 2019). Inhibition of SUMO-1 by ginkgoic acid alleviated myocardial infarction-induced heart dysfunction and fibrosis, and the SUMOylated PML/Pin1/TGF- $\beta 1$ pathway is crucial for ginkgoic acid-inhibited cardiac fibrosis, wherein Pin1 functions as a positive regulator of TGF- $\beta 1$ mRNA (Qiu et al. 2018). Because the ultimate goal of our study was to illuminate the relationship between BAFF signal and interstitial degeneration of renal tubular epithelial cells, we did not delve into the downstream signal pathway. This was the weakness of this study. We will continue to study BAFF signaling and transplantation in depth.

\section{Conclusion}

Although the involvement of BAFF signal in renal disease and allograft rejection has been reported (Xu et al. 2009; Zheng et al. 2017; Kühne et al. 2017), our data firstly provide direct evidence that BAFF signal is associated with renal fibrosis. In spite of the present results obtained from a non-transplant background, they not only elucidate the mechanism underlying the role of BAFF expression in the reduction of the longterm outcome of kidney allografts, but also provide a potential therapeutic target for renal interstitial fibrosis.

Abbreviations RTECs, renal tubular epithelial cells; $B A F F$, B cell activating factor belonging to TNF superfamily; $B A F F-R$, BAFF receptor; $T A C I$, transmembrane activator and CAML interactor; $B C M A$, B cellmaturation antigen

Acknowledgments The authors gratefully acknowledge financial support from the 15th batch of the "six talent peaks" project in Jiangsu Province and the Science and Technology Project of the Changzhou Health Committee of Jiangsu Province (ZD201761).

\section{Declarations}

Conflict of interest The authors declare no competing interests.

Open Access This article is licensed under a Creative Commons Attribution 4.0 International License, which permits use, sharing, adaptation, distribution and reproduction in any medium or format, as long as you give appropriate credit to the original author(s) and the source, provide a link to the Creative Commons licence, and indicate if changes were made. The images or other third party material in this article are included in the article's Creative Commons licence, unless indicated otherwise in a credit line to the material. If material is not included in the article's Creative Commons licence and your intended use is not permitted by statutory regulation or exceeds the permitted use, you will need to obtain permission directly from the copyright holder. To view a copy of this licence, visit http://creativecommons.org/licenses/by/4.0/.

\section{References}

Allison SJ (2015) Fibrosis: targeting EMT to reverse renal fibrosis. Nat Rev Nephrol 11(10):565. https://doi.org/10.1038/nrneph.2015.133

Alturaiki W, McFarlane AJ, Rose K, Corkhill R, McNamara PS, Schwarze J, Flanagan BF (2018) Expression of the B cell differentiation factor BAFF and chemokine CXCL13 in a murine model of respiratory syncytial virus infection. Cytokine 110:267-271. https:// doi.org/10.1016/j.cyto.2018.01.014

Boor P, Floege J (2015) Renal allograft fibrosis: biology and therapeutic targets. Am J Transplant 15(4):863-886. https://doi.org/10.111//ajt. 13180

Chen Y, Wu YR, Yang HY, Li XZ, Jie MM, Hu CJ, Wu YY, Yang SM, Yang YB (2018) Prolyl isomerase Pin1: a promoter of cancer and a 
target for therapy. Cell Death Dis 9(9):883. https://doi.org/10.1038/ s41419-018-0844-y

Friebus-Kardash J, Wilde B, Keles D, Heinold A, Kribben A, Witzke O, Heinemann FM, Eisenberger U (2018) Pretransplant serum BAFF levels are associated with pretransplant HLA immunization and renal allograft survival. Transpl Immunol 47:10-17. https://doi.org/ 10.1016/J.trim.2017.12.004

Grande MT, Sánchez-Laorden B, López-Blau C, De Frutos CA, Boutet A, Arévalo M, Rowe RG, Weiss SJ, López-Novoa JM, Nieto MA (2015) Snail 1-induced partial epithelial-to-mesenchymal transition drives renal fibrosis in mice and can be targeted to reverse established disease. Nat Med 21(9):989-997. https://doi.org/10. 1038/nm.3901

Inoue MK, Nakatsu Y, Yamamotoya T, Hasei S, Kanamoto M, Naitou M, Matsunaga Y, Sakoda H, Fujishiro M, Ono H, Kushiyama A, Asano T (2019) Pin1 plays essential roles in NASH development by modulating multiple target proteins. Cells 8(12):1545. https://doi. org/10.3390/cells 8121545

Ittah M, Miceli-Richard C, Gottenberg JE, Sellam J, Eid P, Lebon P, Pallier C, Lepajolec C, Mariette X (2008) Viruses induce high expression of BAFF by salivary gland epithelial cells through TLRand type-1 IFN-dependent and independent pathways. Eur J Immunol 38(4):1058-1064. https://doi.org/10.1002/eji.200738013

Ittah M, Miceli-Richard C, Gottenberg JE, Sellam J, Lepajolec C, Mariette X (2009) B-cell-activating factor expressions in salivary epithelial cells after dsRNA virus infection depends on RNAactivated protein kinase activation. Eur J Immunol 39(5):12711279. https://doi.org/10.1002/eji.200839086

Jackson SW, Davidson A (2019) BAFF inhibition in SLE-is tolerance restored? Immunol Rev 292(1):102-119. https://doi.org/10.1111/ imr. 12810

Kim MR, Choi HK, Cho KB, Kim HS, Kang KW (2009) Involvement of Pin1 induction in epithelial-mesenchymal transition of tamoxifenresistant breast cancer cells. Cancer Sci 100(10):1834-1841. https:// doi.org/10.1111/j.1349-7006.2009.01260.x

Kühne L, Jung B, Poth H, Schuster A, Wurm S, Ruemmele P, Banas B, Bergler T (2017) Renal allograft rejection, lymphocyte infiltration, and de novo donor-specific antibodies in a novel model of nonadherence to immunosuppressive therapy. BMC Immunol 18(1): 52. https://doi.org/10.1186/s12865-017-0236-6

Lahiri A, Varin MM, le Pottier L, Pochard P, Bendaoud B, Youinou P, Pers JO (2014) Specific forms of BAFF favor BAFF receptormediated epithelial cell survival. J Autoimmun 51:30-37. https:// doi.org/10.1016/j.jaut.2014.02.004

Lefaucheur C, Loupy A (2018) Antibody-mediated rejection of solidorgan allografts. $N$ Engl J Med 379(26):2580-2582. https://doi. org/10.1056/NEJMc1813976

Liu BC, Tang TT, Lv LL (2019) How tubular epithelial cell injury contributes to renal fibrosis. Adv Exp Med Biol 1165:233-252. https:// doi.org/10.1007/978-981-13-8871-2 11

Liu X, Liang E, Song X, Du Z, Zhang Y, Zhao Y (2016) Inhibition of Pin1 alleviates myocardial fibrosis and dysfunction in STZ-induced diabetic mice. Biochem Biophys Res Commun 479(1):109-115. https://doi.org/10.1016/j.bbrc.2016.09.050

Lovisa S, LeBleu VS, Tampe B, Sugimoto H, Vadnagara K, Carstens JL, Wu CC, Hagos Y, Burckhardt BC, Pentcheva-Hoang T, Nischal H, Allison JP, Zeisberg M, Kalluri R (2015) Epithelial-tomesenchymal transition induces cell cycle arrest and parenchymal damage in renal fibrosis. Nat Med 21(9):998-1009. https://doi.org/ $10.1038 / \mathrm{nm} .3902$

Lu X, Chen M, Shen J, Xu Y, Wu H (2019) IL-1 $\beta$ functionally attenuates ABCG2 and PDZK1 expression in HK-2 cells partially through NFKB activation. Cell Biol Int 43(3):279-289. https://doi.org/10.1002/ cbin. 11100

Mackay F, Schneider P (2009) Cracking the BAFF code. Nat Rev Immunol 9(7):491-502. https://doi.org/10.1038/nri2572
Majo J, Klinkhammer BM, Boor P, Tiniakos D (2019) Pathology and natural history of organ fibrosis. Curr Opin Pharmacol 49:82-89. https://doi.org/10.1016/j.coph.2019.09.009

Matsuura I, Chiang KN, Lai CY, He D, Wang G, Ramkumar R, Uchida T, Ryo A, Lu K, Liu F (2010) Pin1 promotes transforming growth factor-beta-induced migration and invasion. J Biol Chem 285(3): 1754-1764. https://doi.org/10.1074/jbc.M109.063826

McNamara PS, Fonceca AM, Howarth D, Correia JB, Slupsky JR, Trinick RE, Al Turaiki W, Smyth RL, Flanagan BF (2013) Respiratory syncytial virus infection of airway epithelial cells, in vivo and in vitro, supports pulmonary antibody responses by inducing expression of the B cell differentiation factor BAFF. Thorax 68(1):76-81. https://doi.org/10.1136/thoraxjnl-2012202288

Nakada S, Kuboki S, Nojima H, Yoshitomi H, Furukawa K, Takayashiki T, Takano S, Miyazaki M, Ohtsuka M (2019) Roles of Pin1 as a key molecule for EMT induction by activation of STAT3 and NF-kB in human gallbladder cancer. Ann Surg Oncol 26(3):907-917. https:// doi.org/10.1245/s10434-018-07132-7

Nakatsu Y, Matsunaga Y, Ueda K, Yamamotoya T, Inoue Y, Inoue MK, Mizuno Y, Kushiyama A, Ono H, Fujishiro M, Ito H, Okabe T, Asano T (2020) Development of Pin1 inhibitors and their potential as therapeutic agents. Curr Med Chem 27(20):3314-3329. https:// doi.org/10.2174/0929867325666181105120911

Nakatsu Y, Matsunaga Y, Yamamotoya T, Ueda K, Inoue Y, Mori K, Sakoda H, Fujishiro M, Ono H, Kushiyama A, Asano T (2016) Physiological and pathogenic roles of prolyl isomerase Pin1 in metabolic regulations via multiple signal transduction pathway modulations. Int J Mol Sci 17(9):1495. https://doi.org/10.3390/ ijms 17091495

Nguan CY, Du C (2009) Renal tubular epithelial cells as immunoregulatory cells in renal allograft rejection. Transplant Rev (Orlando) 23(3):129-138. https://doi.org/10.1016/j.trre.2009.02.003

Panzer SE (2020) Anti-BAFF therapy: a new tool to target B cells in antibody-mediated rejection? Transplantation 104(1):e3-e4. https://doi.org/10.1097/TP.0000000000002993

Qiu F, Dong C, Liu Y, Shao X, Huang D, Han Y, Wang B, Liu Y, Huo R, Paulo P, Zhang ZR, Zhao D, Chu WF (2018) Pharmacological inhibition of SUMO-1 with ginkgolic acid alleviates cardiac fibrosis induced by myocardial infarction in mice. Toxicol Appl Pharmacol 345:1-9. https://doi.org/10.1016/j.taap.2018.03.006

Schneider P, Mackay F, Steiner V, Hofmann K, Bodmer JL, Holler N, Ambrose C, Lawton P, Bixler S, Acha-Orbea H, Valmori D, Romero P, Werner-Favre C, Zubler RH, Browning JL, Tschopp J (1999) BAFF, a novel ligand of the tumor necrosis factor family, stimulates B cell growth. J Exp Med 189(11):1747-1756. https:// doi.org/10.1084/jem.189.11.1747

Schwarting A, Relle M, Meineck M, Föhr B, Triantafyllias K, Weinmann A, Roth W, Weinmann-Menke J (2018) Renal tubular epithelial cell-derived BAFF expression mediates kidney damage and correlates with activity of proliferative lupus nephritis in mouse and men. Lupus 27(2):243-256. https://doi.org/10.1177/0961203317717083

Secreto F, Manske M, Price-Troska T, Ziesmer S, Hodge LS, Ansell SM, Cerhan JR, Novak AJ (2014) B-cell activating factor-receptor specific activation of tumor necrosis factor receptor associated factor 6 and the phosphatidyl inositol 3-kinase pathway in lymphoma B cells. Leuk Lymphoma 55(8):1884-1892. https://doi.org/10.3109/ 10428194.2013 .862619

Shen ZJ, Braun RK, Hu J, Xie Q, Chu H, Love RB, Stodola LA, Rosenthal LA, Szakaly RJ, Sorkness RL, Malter JS (2012) Pin1 protein regulates Smad protein signaling and pulmonary fibrosis. J Biol Chem 287(28):23294-23305. https://doi.org/10.1074/jbc. M111.313684

Shen ZJ, Esnault S, Malter JS (2005) The peptidyl-prolyl isomerase Pin1 regulates the stability of granulocyte-macrophage colony- 
stimulating factor mRNA in activated eosinophils. Nat Immunol 6(12):1280-1287. https://doi.org/10.1038/ni1266

Shen ZJ, Hu J, Shiizaki K, Kuro-o M, Malter JS (2016) Phosphateinduced renal fibrosis requires the prolyl isomerase Pin1. PLoS One 11(2):e0150093. https://doi.org/10.1371/journal.pone.0150093

Valente MJ, Henrique R, Costa VL, Jerónimo C, Carvalho F, Bastos M, de Pinho PG, Carvalho M (2011) A rapid and simple procedure for the establishment of human normal and cancer renal primary cell cultures from surgical specimens. PLoS One 6(5):e19337

Verdecia MA, Bowman ME, Lu KP, Hunter T, Noel JP (2000) Structural basis for phosphoserine-proline recognition by group IV WW domains. Nat Struct Biol 7(8):639-643. https://doi.org/10.1038/77929

Wang R, Yan Y, Li C (2019) LINC00462 is involved in high glucoseinduced apoptosis of renal tubular epithelial cells via AKT pathway. Cell Biol Int 44(1):286-294. https://doi.org/10.1002/cbin.11231

Wu D, Huang D, Li LL, Ni P, Li XX, Wang B, Han YN, Shao XQ, Zhao D, Chu WF, Li BY (2019) TGF- $\beta 1$-PML SUMOylation-peptidylprolyl cis-trans isomerase NIMA-interacting 1 (Pin1) form a positive feedback loop to regulate cardiac fibrosis. J Cell Physiol 234(5): 6263-6273. https://doi.org/10.1002/jcp.27357

Xu H, He X, Sun J, Shi D, Zhu Y, Zhang X (2009) The expression of Bcell activating factor belonging to tumor necrosis factor superfamily
(BAFF) significantly correlated with C4d in kidney allograft rejection. Transplant Proc 41(1):112-116. https://doi.org/10.1016/j. transproceed.2008.10.037

Xu H, He X, Zhao W, Guo H, Shi Q, Zhu Y, Zhang X (2012) CD256 can be found in antibody-mediated renal allograft rejection tissues. Clin Lab 58(5-6):411-418

$\mathrm{Xu}$ W, Santini PA, Matthews AJ, Chiu A, Plebani A, He B, Chen K, Cerutti A (2008) Viral double-stranded RNA triggers Ig class switching by activating upper respiratory mucosa B cells through an innate TLR3 pathway involving BAFF. J Immunol 181(1):276287. https://doi.org/10.4049/jimmunol.181.1.276

Yang JW, Hien TT, Lim SC, Jun DW, Choi HS, Yoon JH, Cho IJ, Kang KW (2014) Pin1 induction in the fibrotic liver and its roles in TGFbeta1 expression and Smad2/3 phosphorylation. J Hepatol 60(6): 1235-1241. https://doi.org/10.1016/j.jhep.2014.02.004

Zheng N, Fan J, Wang B, Wang D, Feng P, Yang Q, Yu X (2017) Expression profile of BAFF in peripheral blood from patients of IgA nephropathy: correlation with clinical features and streptococcus pyogenes infection. Mol Med rep 15(4):1925-1935. https://doi. org/10.3892/mmr.2017.6190 